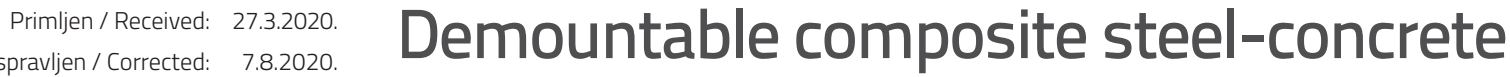 \\ Prihvaćen / Accepted: 10.8.2020. \\ floors: A state-of-the-art review
}

Dostupno online / Available online: 10.4.2021.

Authors:

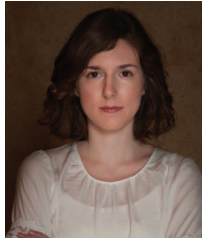

Isidora Jakovljević, MSc. CE

University of Belgrade, Serbia

Faculty of Civil Engineering

isidora@imk.grf.bg.ac.rs

Corresponding author

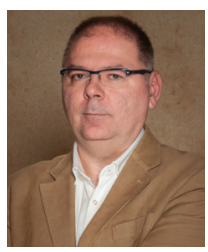

Assist. Prof. Milan Spremić, PhD. CE

University of Belgrade, Serbia

Faculty of Civil Engineering

spremic@imk.grf.bg.ac.rs

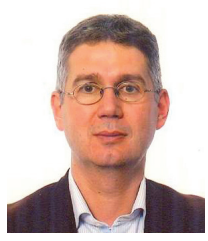

Prof. Zlatko Marković, PhD. CE

University of Belgrade, Serbia

Faculty of Civil Engineering

zlatko@imk.grf.bg.ac.rs
Isidora Jakovljević, Milan Spremić, Zlatko Marković

Subject review

\section{Demountable composite steel-concrete floors: A state-of-the-art review}

In keeping with current demands for sustainable development in all segments of the industry, numerous research in the field of steel-concrete composite structures has been focused on developing demountable shear connectors. In the past years, various demountable shear connectors have been suggested, with various mechanisms for transferring shear force between a steel profile and a concrete or composite slab. In this paper, a state of the art on the topic is given, and experimental and numerical research results of push-out and beam tests are summarized.

\section{Key words:}

demountable shear connectors, friction-grip bolts, threaded headed studs, blind bolts, embedded nuts, coupler system, clamping connector

Pregledni rad

Isidora Jakovljević, Milan Spremić, Zlatko Marković

Demontažne spregnute međukatne konstrukcije od čelika i betona: pregled najnovijih izvedbi

U skladu sa zahtjevima za održivi razvoj u svim segmentima industrije, brojna su istraživanja u području spregnutih čelično-betonskih konstrukcija usmjerena na razvoj demontažnih sredstava za sprezanje. Proteklih godina predlagana su različita demontažna sredstva za sprezanje koja su različitim mehanizmima prenosila posmičnu silu između čeličnog profila i betonske ili spregnute ploče. U ovom radu prikazana su najnovija dostignuća na tu temu dajući sažetke eksperimentalnih i numeričkih rezultata istraživanja vezano uz potisna (push-out) ispitivanja i ispitivanja na nosačima.

Ključne riječi:

demontažna sredstva za sprezanje, vijci za tarne spojeve, moždanici s glavom i navojem, slijepi vijci, ugradene matice vijka, sustav sa spojnicom, sredstva za sprezanje sa stezaljkom

Übersichtsarbeit

Isidora Jakovljević, Milan Spremić, Zlatko Marković

Demontage-Verbunddeckenkonstruktionen aus Stahl und Beton: Übersicht der neuesten Ausführungen

In Übereinstimmung mit den Forderungen nach der nachhaltigen Entwicklung in allen Industriesegmenten sind zahlreiche Forschungen auf dem Gebiet von VerbundStahlbetonkonstruktionen auf die Entwicklung von Verbund-Demontagemitteln ausgerichtet. In den vergangenen Jahren wurden verschiedene Demontage-Verbundmittel vorgeschlagen, welche mitden verschiedenen Mechanismen die Scherkraft zwischen dem Stahlprofil, sowie der Betonoder Verbundplatte übertragen haben. In dieser Arbeit wurden die neusten Errungenschaften zu diesem Thema dargestellt, indem die Zusammenfassungen von experimentalen und nummerischen Forschungsergebnissen dargestellt wurden, im Zusammenhang mit den Schiebeprüfungen (push-out-Prüfungen), sowie den Prüfungen auf den Trägern.

Schlüsselwörter:

Demontage-Verbundmittel, Schrauben für die Reibungsverbindungen, Dübel mit dem Kopf und Sturz, Blindschrauben, eingebaute Mutter, System mit der Verbindungsfuge, Verbundmittel mit der Klemme 


\section{Introduction}

The application of steel-concrete composite structures in the building industry has been increasing since the mid $20^{\text {th }}$ century. The implementation of these structural systems presents quite a few advantages, including reduction in self-weight and increased speed of construction. The most common steel-concrete composite system is a downstand composite beam that consists of a steel profile connected via welded headed stud shear connectors to a concrete deck. Concrete deck is often cast in profiled metal sheeting, forming a composite slab.

In the past decades, much research has been performed in the field of steel-concrete composite structures with the purpose of crossing larger spans, decreasing floor self-weight, and minimizing floor depth. Various systems, such as composite slim-floor beams, delta beams, and ultra-shallow floor systems, have been developed [1]. In order to optimize construction time, alternative shear connectors with pins and screws have been suggested [2].

On the other hand, environmental issues have been brought into focus, implying sustainable development in all segments of the industry. In other words, recycling of building material and reuse of constructional elements have been requested. For that reason, numerous research has been conducted to further develop demountable steel-concrete composite structures, with an emphasis on shear connections between the steel flange and concrete deck applied in such systems. A recent study on environmental benefits of various composite floor structures has shown that demountable steel-concrete systems lead to highest savings with regard to emissions and resources in most of the analysed impact categories [3].

Although welded headed stud shear connectors are still the most widely used shear connectors, they can not be applied in their original form in the case of structure demounting, during deconstruction, or during building modification and repair. Various demountable shear connectors have been suggested, experimentally tested and numerically analysed by several authors and research groups, often in cooperation with industry partners. A major role in deconstructability of composite structures is assumed by bolted shear connectors which, by different mechanisms, transfer shear force between a steel profile and a concrete or composite slab.

A state of the art on this topic is given in this paper so as to provide a clear outline of all the solutions on demountable composite steel-concrete floor systems that have been proposed so far. The main results on experimental and numerical research of the push-out and beam tests published in past years are presented, compared, and discussed. To get a better overview of the topic, shear connectors are classified by their geometry and load-carrying mechanisms, and each type is briefly presented in a separate section. Additionally, published studies conducted on demountable shear connectors are summarized and chronologically listed in Table 1.

Table 1. Summarized research conducted on shear connectors in demountable steel-concrete floor systems

\begin{tabular}{|c|c|c|c|c|c|c|}
\hline Ref. & Year & Authors & Types of analysed shear connectors & 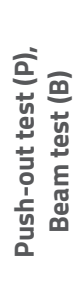 & 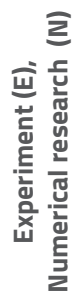 & 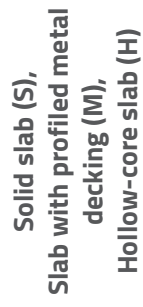 \\
\hline [4] & 1968 & Dallam & friction-grip bolts & $P$ & E & $\mathrm{S}$ \\
\hline [5] & 1968 & Dallam, Harpster & friction-grip bolts & B & $\mathrm{E}$ & S \\
\hline [6] & 1971 & Marshall, Nelson, Banerjee & friction-grip bolts & $P, B$ & E & S \\
\hline [7] & 1984 & Dedic, Klaiber & $\begin{array}{l}\text { bolts with embedded nuts, bolts with } \\
\text { epoxy resin }\end{array}$ & $P$ & E & S \\
\hline [8] & 1987 & Hawkins & bolts without embedded nuts & P & E & S \\
\hline [9] & 2003 & Sedlecek, Hoffmeister, et al. & bolts with embedded nuts & $P$ & E & S \\
\hline [10] & 2010 & Kwon, Engelhardt, Klingner & $\begin{array}{l}\text { friction-grip bolts, bolts with embedded } \\
\text { nuts, adhesive anchors }\end{array}$ & $P$ & $E$ & S \\
\hline [11] & 2011 & Kwon, Engelhardt, Klingner & $\begin{array}{l}\text { friction-grip bolts, bolts with embedded } \\
\text { nuts, adhesive anchors }\end{array}$ & B & $E$ & S \\
\hline
\end{tabular}




\begin{tabular}{|c|c|c|c|c|c|c|}
\hline Ref. & Year & Authors & Types of analysed shear connectors & 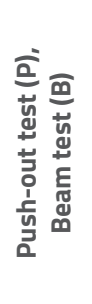 & 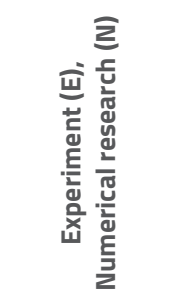 & 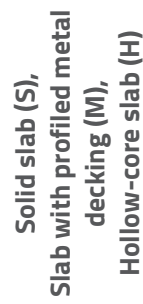 \\
\hline [12] & 2012 & Kwon, Engelhardt, Klingner & $\begin{array}{l}\text { friction-grip bolts, bolts with embedded } \\
\text { nuts, adhesive anchors }\end{array}$ & B & N & S \\
\hline [13] & 2013 & $\begin{array}{c}\text { Pavlović, Marković, Veljković, } \\
\text { Buđevac }\end{array}$ & bolts with embedded nuts & $\mathrm{P}$ & $\mathrm{E}, \mathrm{N}$ & S \\
\hline [14] & 2014 & Chen, Zhao, West, Walbridge & friction-grip bolts, welded headed studs & $P, B$ & $\begin{array}{l}\mathrm{E} \text { (push-out), } \\
\mathrm{N} \text { (beam) }\end{array}$ & S \\
\hline [15] & 2014 & Moynihan, Allwood & bolts with embedded nuts & B & $\mathrm{E}$ & M \\
\hline [16] & 2015 & Liu, Bradford, Lee & friction-grip bolts & $P$ & $\mathrm{E}, \mathrm{N}$ & S \\
\hline [17] & 2015 & Dai, Lam, Saveri & $\begin{array}{c}\text { threaded headed studs, welded headed } \\
\text { studs }\end{array}$ & $\mathrm{P}$ & $E, N$ & $\mathrm{~S}$ \\
\hline [18] & 2015 & Henderson, Zhu, Uy, Mirza & blind bolts, welded headed studs & $\mathrm{P}$ & $\mathrm{E}$ & S \\
\hline [19] & 2015 & Henderson, Zhu, Uy, Mirza & blind bolts, welded headed studs & $\mathrm{P}$ & N & $\mathrm{S}$ \\
\hline [20] & 2015 & $\begin{array}{l}\text { Ban, Uy, Pathirana, } \\
\text { Henderson, Mirza, Zhu }\end{array}$ & blind bolts, welded headed studs & B & $\mathrm{E}$ & $\mathrm{s}$ \\
\hline [21] & 2015 & Pathirana, Uy, Mirza, Zhu & blind bolts, welded headed studs & $P, B$ & $\begin{array}{l}\text { E (push-out), } \\
\text { N (beam) }\end{array}$ & S \\
\hline [22] & 2016 & Liu, Bradford, Chen, Ban & friction-grip bolts & B & N & S \\
\hline [23] & 2016 & Ataei, Bradford, Liu & $\begin{array}{l}\text { friction-grip bolts, bolts with embedded } \\
\text { nuts }\end{array}$ & B & $\mathrm{E}$ & S \\
\hline [24] & 2016 & Rehman, Lam, Dai, Ashour & threaded headed studs & $P$ & $\mathrm{E}$ & M \\
\hline [25] & 2016 & Pathirana, Uy, Mirza, Zhu & blind bolts, welded headed studs & B & $\mathrm{E}, \mathrm{N}$ & $\mathrm{S}$ \\
\hline [26] & 2016 & Pathirana, Uy, Mirza, Zhu & blind bolts,welded headed studs & $P$ & $\mathrm{E}, \mathrm{N}$ & $\mathrm{s}$ \\
\hline [27] & 2017 & Liu, Bradford, Ataei & friction-grip bolts & B & N & S \\
\hline [28] & 2017 & Wang, Guo, Jia, Chen, Dong & threaded headed studs & $\mathrm{P}$ & E & S \\
\hline [29] & 2017 & Suwaed, Karavasilis & locking-nut shear connector & $P$ & $E$ & $S$ \\
\hline [30] & 2018 & Rehman, Lam, Dai, Ashour & $\begin{array}{l}\text { threaded headed studs, welded headed } \\
\text { studs }\end{array}$ & B & $\mathrm{E}$ & M \\
\hline [31] & 2018 & Yang, Lam, Dai, Sheehan & threaded headed studs & $P$ & $\mathrm{E}$ & M \\
\hline [32] & 2018 & $\begin{array}{l}\text { Dai, Lam, Sheehan, Yang, } \\
\text { Zhou }\end{array}$ & bolts with embedded nuts & $\mathrm{P}$ & $\mathrm{E}, \mathrm{N}$ & M \\
\hline
\end{tabular}




\begin{tabular}{|c|c|c|c|c|c|c|}
\hline Ref. & Year & Authors & Types of analysed shear connectors & 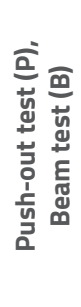 & 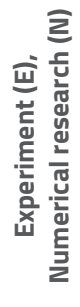 & 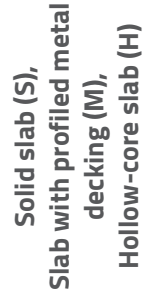 \\
\hline [33] & 2018 & Yang, Liu, Jiang, Xin & $\begin{array}{c}\text { bolts with a coupler system, welded } \\
\text { headed studs }\end{array}$ & $\mathrm{P}$ & $E$ & $\mathrm{~S}$ \\
\hline [34] & 2018 & Suwaed, Karavasilis & friction-based shear connector & $\mathrm{P}$ & E & S \\
\hline [35] & 2019 & $\begin{array}{l}\text { Balkos, Sjaarda, West, } \\
\text { Walbridge }\end{array}$ & friction-grip bolts & B & $E$ & S \\
\hline [36] & 2019 & $\begin{array}{c}\text { Kozma, Odenbreit, Braun, } \\
\text { Veljkovic, Nijgh }\end{array}$ & $\begin{array}{l}\text { friction-grip bolts, bolts with a coupler } \\
\text { system with and without injected resin }\end{array}$ & $\mathrm{P}$ & E & $\mathrm{S}, \mathrm{M}$ \\
\hline [37] & 2019 & Odenbreit, Kozma & $\begin{array}{l}\text { friction-grip bolts, bolts with a coupler } \\
\text { system with injected resin }\end{array}$ & B & $\mathrm{E}, \mathrm{N}$ & $\mathrm{M}$ \\
\hline [38] & 2019 & Sencu, Wang, Yang, Lam & threaded headed studs & $P$ & $E$ & M \\
\hline [39] & 2019 & Ataei, Zeynalian, Yazdi & bolts with embedded nuts & $P$ & $E$ & S \\
\hline [40] & 2019 & Nijgh, Girbacea, Veljkovic & $\begin{array}{c}\text { bolts with a coupler system with } \\
\text { injected resin }\end{array}$ & B & $E, N$ & S \\
\hline [41] & 2019 & $\begin{array}{c}\text { Feidaki, Vasdravellis, He, } \\
\text { Wang }\end{array}$ & $\begin{array}{l}\text { steel-yielding demountable shear } \\
\text { connector }\end{array}$ & $\mathrm{P}$ & $E, N$ & $\mathrm{H}$ \\
\hline [42] & 2019 & Wang, Webster, Hajjar & clamping connector & $P$ & E & S \\
\hline
\end{tabular}

\section{Friction-grip bolts}

Friction-grip bolts are the most widely studied and analysed demountable shear connectors. These bolts are preloaded, hence shear force in the composite connection is transferred through friction between the concrete slab and top flange of a steel beam. In the literature, they are often referred to as high-strength friction-grip bolts.

Initial publications on the experimental beam and push-out tests on friction-grip bolts appeared in the late 1960s [4-6]. Experimental investigations covered various parameters, such as concrete strength, beam span, load geometry, bolt diameter, and in-situ and prefabricated concrete slabs. Main conclusions were made on the observed full interaction between a concrete slab and a steel beam in the serviceability load range.

A few years later, some of the research results were implemented in the British standard for bridge design [43]. The mentioned standard requests compliance with the following condition when designing bridges with friction-grip bolts: longitudinal shear resistance developed by friction should be larger than longitudinal shear force at the serviceability limit state. The equation for obtaining shear resistance is prescribed as:

$F_{u}=\mu \cdot F_{p c} / 1.2$

where $F_{p c}$ is the preloading force and $\mu$ is the slip factor that should be taken as 0.45 . The standard refers to the loss of preloading force in bolts over time due to concrete creep and shrinkage effects but does not specify a method to account for these effects.

The research on friction-grip bolts has regained popularity in recent years. Three different types of shear connectors, including friction-grip bolts, have been tested, all with the purpose of creating a composite action in the existing noncomposite bridges by post-installation of bolts [10-12]. The research included single bolt shear tests under static and fatigue loading, experimental large-scale beam tests, and finite element numerical simulations of beam tests. Bolts were inserted in the holes predrilled in a concrete slab, pretension force was applied, and the holes were filled with high-strength grout, as shown in Figure 1. 


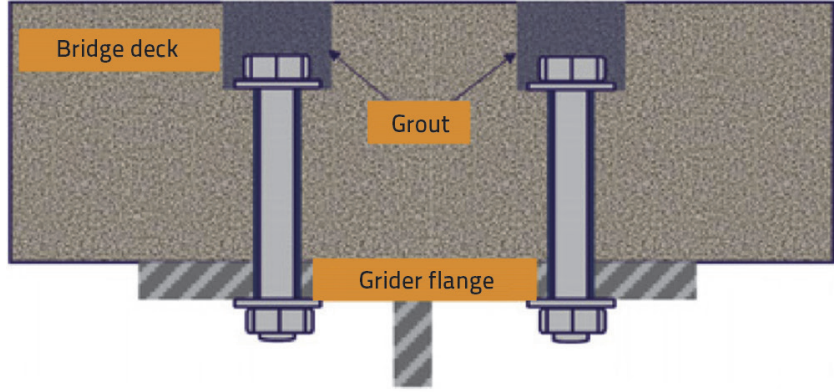

Figure 1. Composite connection achieved with friction-grip bolts in a bridge rehabilitation work [10]

It was reported that high-tension friction-grip bolts showed notably higher fatigue strength than conventional welded shear studs, as a result of elimination of weld between the flange and connector, which turned to be an important advantage in the design of composite bridges. Beam specimens with post-installed shear connectors showed up to $50 \%$ increase in stiffness and strength compared to noncomposite beams, although they were designed with the $30 \%$ shear connection ratio only. Authors [12] suggested calculation of static strength of post-installed shear connectors using the following equation:

$F_{u}=0.6 A_{s} \cdot f_{u}$

where $A_{s}$ is the effective shear area of shear connector and $f_{u}$ is the ultimate tensile strength of the shear connector material.

Another contribution to this field of study was made through implementation of the friction-grip bolted shear connectors in precast geopolymer concrete slabs [16, 22, $23,27]$. Push-out and beam tests were performed and the corresponding numerical models were developed, according to the arrangement presented in Figure 2. Beams with postinstalled friction-grip bolts in prefabricated slabs showed lower ultimate capacity, but higher ductility than the beam with embedded bolts inside the monolithic slab, which was also experimentally tested. The general weakness of the analysed system was attributed to the gaps between precast concrete slabs that led to considerable reduction of the initial stiffness. To demonstrate the system demountability, during both push-out and beam tests, after
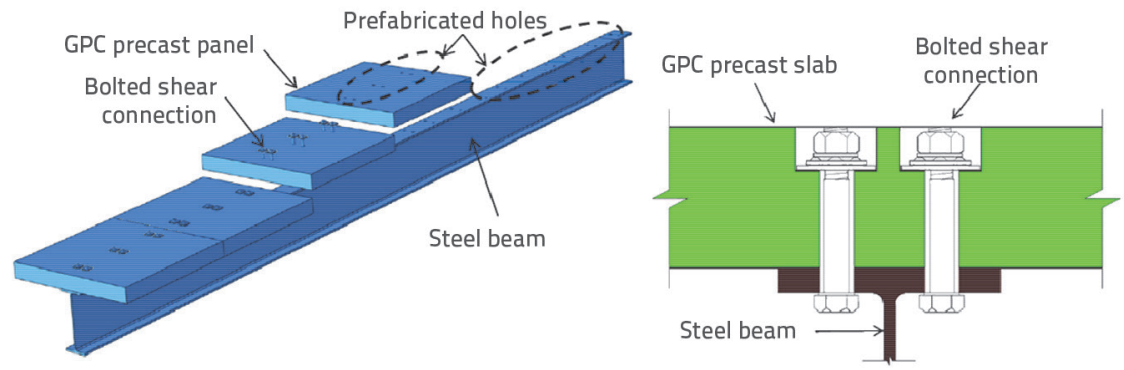

Figure 2. Implementation of friction-grip bolts in precast slabs [23] loading within serviceability range, some specimens were reassembled and then loaded again until failure, resulting in load-slip behaviour similar to that of specimens that were not demounted. A slight modification of Eq. (2) for shear strength of friction-grip bolts in geopolymer concrete slabs was suggested [16]:

$F_{u}=0.66 A_{s} \cdot f_{u}$

A proposed simplified load-slip relationship typical for frictiongrip bolts, including a linear and nonlinear part, is presented in Figure 3 [16]. Three regimes of shear connector behaviour can be observed. In the first regime, slip is almost negligible because of the applied pretension. Then, once the friction at the steel-concrete interface induced by preload is overcome, some slip occurs due to clearance between prefabricated holes and bolts. The slip is close to the sum of the clearance between a steel flange hole and a bolt and the clearance between a concrete slab hole and a bolt. In the third part, after this slip is overcome, a nonlinear relation between the load and slip can be observed. The analytical formulation for modelling shear connection in composite beams using pretensioned bolts was suggested, including the mentioned three stages of bolt behaviour [44].

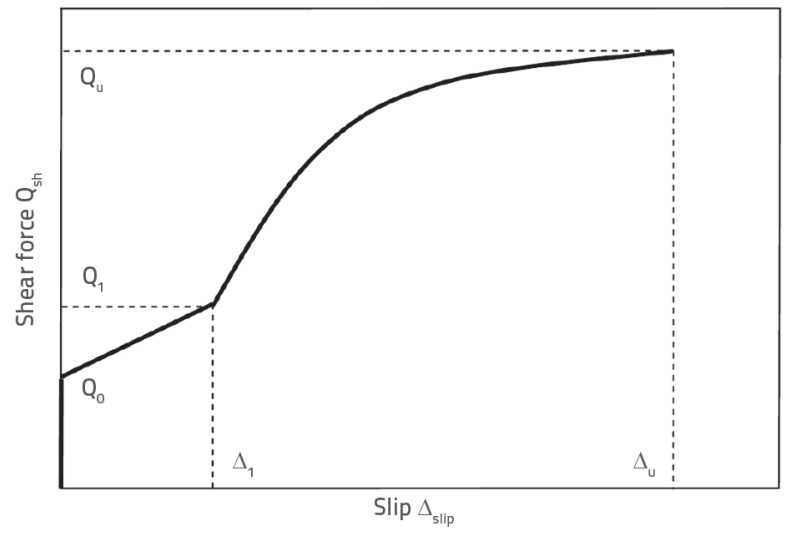

Figure 3. Design recommendation of load-slip relationship for friction-grip bolts [16]

In further experimental work, some refined solutions were proposed in order to improve the deformation response and decrease the maximum slip value. The use of the so-called through-bolts in steel-precast composite bridges was suggested [14, 35]. Bolt holes were formed using PVC pipes, which were placed at specified places along the concrete slab so that the space inside pipes was left unfilled after concrete casting, as shown in Figure 4.a. The research covered push-out and beam tests, and focused on several parameters 
Table 2. Experimental results of push-out test conducted on friction-grip bolts in solid slabs

\begin{tabular}{|c|c|c|c|c|c|c|c|c|c|}
\hline Ref. & $\begin{array}{c}\text { Bolt } \\
\text { diameter } \\
{[\mathrm{mm}]}\end{array}$ & $\begin{array}{c}\text { Slab hole } \\
\text { or cylinder } \\
\text { diameter } \\
{[\mathrm{mm}]}\end{array}$ & $\begin{array}{c}\text { Steel flange } \\
\text { hole diameter } \\
{[\mathrm{mm}]}\end{array}$ & $\begin{array}{c}\text { Bolt } \\
\text { material } \\
\text { grade }\end{array}$ & $\begin{array}{c}\text { Bolt } \\
\text { tensile } \\
\text { strength, } \\
\mathbf{f}_{\mathrm{u}} \\
{[\mathrm{MPa}]}\end{array}$ & $\begin{array}{c}\text { Concrete } \\
\text { strength } \\
\text { [MPa] }\end{array}$ & $\begin{array}{c}\text { Ultimate load } \\
\text { per connector } \\
{[\mathrm{kN}]}\end{array}$ & $\begin{array}{l}\text { Maximum } \\
\text { slip } \\
{[\mathrm{mm}]}\end{array}$ & Remark \\
\hline \multirow{3}{*}{ [14] } & 19.05 & 25 & - & $\begin{array}{l}\text { ASTM } \\
\text { A325* }\end{array}$ & - & $\begin{array}{c}49.65 \\
\text { (cylinder) }\end{array}$ & 128.1 & 11.1 & \multirow{3}{*}{$\begin{array}{l}\text { bolts cast in PVC } \\
\text { cylinders }\end{array}$} \\
\hline & 15.88 & 25 & - & $\begin{array}{l}\text { ASTM } \\
\text { A325* }\end{array}$ & - & $\begin{array}{c}49.65 \\
\text { (cylinder) }\end{array}$ & 82.5 & 11.7 & \\
\hline & 12.70 & 25 & - & $\begin{array}{l}\text { ASTM } \\
\text { A325* }\end{array}$ & - & $\begin{array}{c}49.65 \\
\text { (cylinder) }\end{array}$ & 53.8 & 11.1 & \\
\hline \multirow{3}{*}{ [16] } & 20.00 & 24 & 24 & 8.8 & 1020 & $\begin{array}{c}47.00 \\
\text { (cylinder) }\end{array}$ & 219.5 & 24.8 & \multirow{3}{*}{$\begin{array}{l}\text { geopolymer } \\
\text { concrete slabs }\end{array}$} \\
\hline & 20.00 & 28 & 24 & 8.8 & 1020 & $\begin{array}{c}47.00 \\
\text { (cylinder) }\end{array}$ & 216.0 & 27.5 & \\
\hline & 16.00 & 24 & 24 & 8.8 & 1020 & $\begin{array}{c}47.00 \\
\text { (cylinder) }\end{array}$ & 153.0 & 29.5 & \\
\hline [36] & 20.00 & - & 24 & 8.8 & - & $\begin{array}{l}59.40 \\
\text { (cube) }\end{array}$ & 141.0 & 9.7 & $\begin{array}{l}\text { bolts cast in steel } \\
\text { cylinders }\end{array}$ \\
\hline
\end{tabular}

influencing the connection behaviour: contact surface, bolt diameter, and pretension load level.

Another solution applicable to building construction was proposed, involving friction-grip bolts that were cast in steel cylinders, which were welded to the top plate and L profile, according to Figure 4.b $[36,37]$. The suggested shear connection was tested by push-out tests in solid concrete slabs and composite slabs with profiled steel sheeting, while the beam test was performed on the composite slab only. A comparison between connections with galvanised and non-galvanised steel elements was made, showing that the galvanised connection changes its behaviour after reassembling, by slip increase and reduction of friction resistance due to fading of the coating layer and decrease of the friction coefficient.
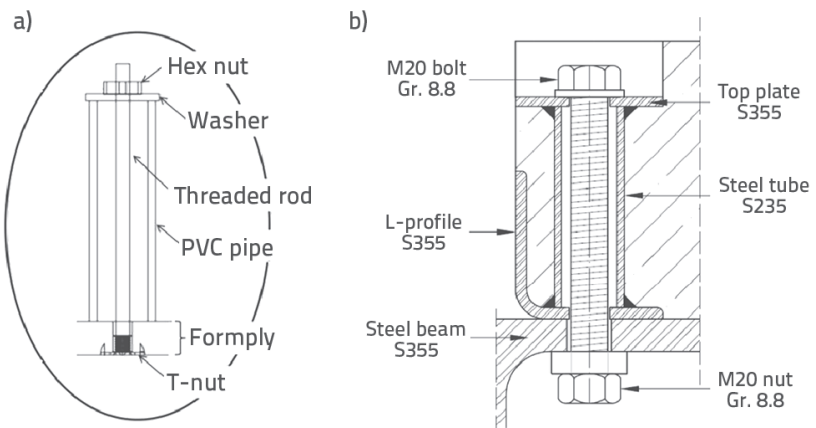

Figure 4. a) Through-bolt [35], b) Friction-grip bolt cast in steel cylinder [36]

A database showing results of push-out tests conducted on friction-grip bolts subjected to full pretension force is presented in Table 2. As can be observed from the results, the maximum slip value, corresponding to the ultimate load level, varies from $10 \mathrm{~mm}$ to nearly $30 \mathrm{~mm}$. The smallest slip of $9.7 \mathrm{~mm}$ is observed in the case of bolts cast in steel cylinders, which can be explained by rigidity of the steel tube. On the other hand, the solution without any additional cylinders leads to final slip that is up to three times larger.

Even though a friction-grip bolt is the most widely investigated type of demountable shear connectors in composite floor structures, complete regulations in design codes considering friction-grip bolts are still lacking. The main shortcoming of this connector could be attributed to durability issues, keeping in mind losses of pretension force over time, usually influenced by fading of the coating layer applied on the steel flange [45]. As a result, after friction is overcome, a certain slip occurs, contributing to additional deformation of the girder.

\section{Bolted shear connectors without embedded nuts. Threaded headed studs}

Compared to friction-grip bolts, bolted shear connectors without embedded nuts do not require pretension, which reduces the time of bolt installation and does not question the loss of bolt preloading force over time. Shear force is completely transferred by shear through threaded part of the bolt and concrete bearing around the bolt. However, because of the bolt slip in the hole, a lower initial stiffness is expected, which affects beam deflections and may induce serviceability issues. First studies on bolted shear connectors without embedded nuts, performed in the 1980s, revealed that stiffness of analysed bolted connectors amounted to only $15 \%$ of the stiffness of 
welded headed studs, while shear capacity was about $80 \%$ of the shear capacity of welded shear connectors [8].

Another approach for achieving demountability of steelconcrete connections involves manufacturing shear connector by threading the body of a headed stud, as shown in Figure 5. In this way, the final product has a geometry similar to the previously described bolts without embedded nuts. In past years, a series of tests followed by numerical simulations were conducted on these connectors installed in both solid slabs and composite slabs with metal decking $[17,24,30,31,38]$. Variations in the length of the threaded and collar part of the stud were covered by such studies, which also focused on concrete strength, reinforcement arrangement in push-out test set-up, shear connector height and temperature level during loading. Compared to welded studs, the behaviour of connections achieved with threaded studs exhibited a notable difference in initial stiffness, as the outcome of the stud-hole clearance, although the ultimate shear strengths were almost the same for both connectors. The full-scale composite beam test demonstrated that the ultimate moment capacity of a demountable beams can be well predicted by the plastic theory [30].

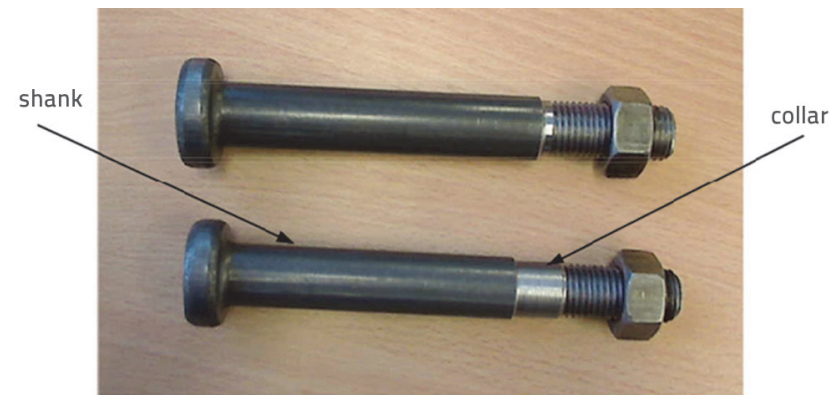

Figure 5. Threaded headed studs [17]

Furthermore, as push-out tests on threaded studs were conducted in both continuous and discontinuous metal decking composite slabs, it was established that connectors in continuous slabs had lower ultimate strength, but higher strength at $6 \mathrm{~mm}$ slip than those in discontinuous slabs [31]. It is important to note that the embedment height showed significant influence on the failure of the profiled composite slab, even though the height of both tested bolts satisfied the Eurocode 4 [46] request for the minimum welded stud height of $2 d$ above the top of the steel deck, where $d$ is the shank diameter.

The study on demountable threaded headed studs in ultra-high performance concrete, which contains evenly embedded steel fibres, is also worth mentioning [28]. To increase deformation capacities of composite shear connections achieved with this type of concrete, welded studs were replaced with threaded studs. However, although push-out tests revealed higher ductility, the slip was still lower than $6 \mathrm{~mm}$, which is requested by Eurocode 4 [46] for ductile connectors.

\section{Bolted shear connectors with embedded nuts}

The idea of using bolted shear connectors with nuts in their base, embedded in a concrete slab, was applied as a means of controlling bolt rotation and slip during loading. In that way, compared to bolts without embedded nuts, an increase in stiffness is expected. Another important advantage of these connectors is related to easier mounting process than for bolts without embedded nuts, which are difficult to keep in vertical position before and during concrete casting. Still, connections achieved with bolts with embedded nuts feature certain bolt-to-hole slip as a result of necessary execution tolerances, provoking additional deflections of the steel beam at the realisation stage [47]. Different connection arrangements were tested in push-out and beam tests, including one or two embedded nuts, and they revealed similar response trend.

In the 1980s, first research steps were made for implementing this type of connectors in the rehabilitation of existing bridges [7]. Bolts with a single embedded nut were mounted in predrilled holes that were afterwards filled with grout, as shown in Figure 6.a. Authors commented on the comparable force-slip behaviour of connections made with bolts and welded studs.

Several static and fatigue push-out tests in solid slabs, involving bolts with two embedded nuts, and including a theoretical model for calculating concrete resistance to crushing and shear resistance of bolts, were conducted at the very beginning of the $21^{\text {st }}$ century [9]. However, it was discovered that experimental results varied considerably from resistance calculations, and it was concluded that further investigations were necessary for making general design recommendations.

More recently, tests on double-nut bolts were performed as a part of a research study including the previously described friction-grip bolts, the purpose being to use them in bridge rehabilitation work [10-12]. A steel-concrete connection layout including bolts with two nuts embedded above a steel flange is presented in Figure 6.b. After filling the gaps with high-strength grout, a full pretension force is applied on double-nut bolts, implying a force-slip relationship similar in shape to the friction-grip bolt response, but with remarkably lower slip at failure.

Another experimental investigation showed that, in comparison with welded headed studs, the shear connection involving bolts with a single embedded nut exhibited stiffness that is by as much as $50 \%$ lower for serviceability loads [13]. The phenomenon was attributed to the presence of a bolt-hole slip, threads-to-hole penetration, and larger contribution of shear force to failure. Further numerical investigations helped in formulation of the bolt failure model, including combined loading involving axial, shear and bending deformation. Comparison of loadslip response obtained from push-out tests of bolts with a 


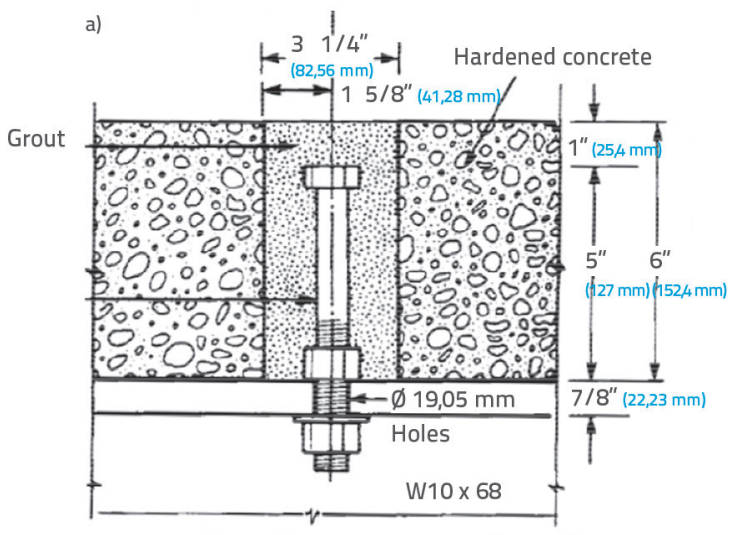

b)

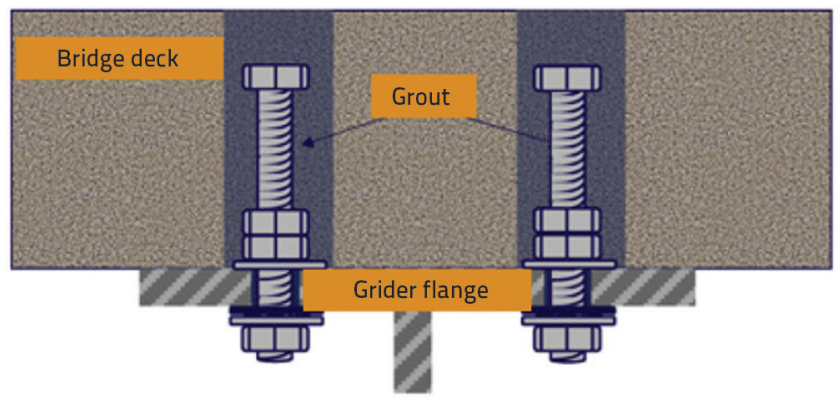

Figure 6. Composite connections in bridge rehabilitation work: a) Single-nut bolt [7]; b) Double-nut bolts [10]

single embedded nut [13], threaded headed studs [17] and welded headed studs [17], all conducted in solid slabs, is given in Figure 7. Although all presented connectors reached a similar ultimate load, the shape of load-slip curves is notably different. As expected, bolts with embedded nuts show increased stiffness compared to threaded headed studs, much closer to the welded studs' stiffness. However, bolts with embedded nuts failed at a very low slip rate due to brittle bolt failure, while concrete crushing occurred for both threaded and welded stud connectors.

\begin{tabular}{|c|c|c|c|}
\hline Ref. & \multicolumn{2}{|c|}{ Shear connector } & $\begin{array}{c}\text { Concrete cube } \\
\text { strength [MPa] }\end{array}$ \\
\hline$[13]$ & bolts with embedded nuts & M16 8.8 & 40 \\
\hline$[17]$ & threaded studs & $18 \mathrm{~mm}^{*}$ & 30 \\
\hline$[17]$ & welded studs & $19 \mathrm{~mm}$ & 30 \\
\hline${ }^{*}$ collar diameter & \\
\hline
\end{tabular}

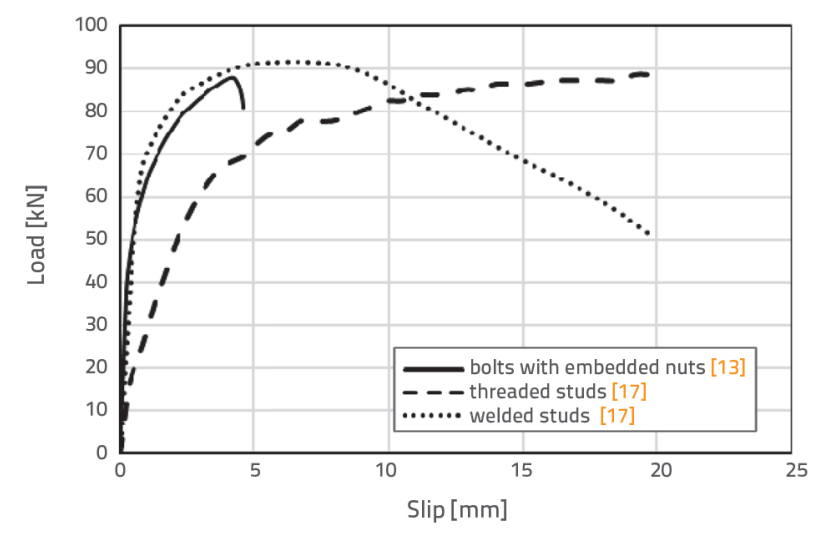

Figure 7. Comparison of shear connector behaviour
Additional insight into features of bolts with the embedded nut was given through experimental testing of three beams of various spans [15]. A concrete slab was cast in profiled steel decking and comparisons with previously performed tests on beams with welded headed studs were made. According to the authors, beams with bolts showed comparative resistance to beams with headed studs - moment capacities were lower in the maximum of $12 \%$. After loading at serviceability loads, two beams were demounted, reassembled and then loaded to failure, resulting in a certain slip increase.

It should however be noted that investigations in this field are still ongoing. Cyclic behaviour of composite connections with single-nut embedded bolts in precast concrete panels has been studied experimentally [39]. Furthermore, experimental and numerical research on the behaviour of bolts with a single embedded nut in continuous, partially discontinuous and separate concrete slabs with metal decking have been published [32]. It was discovered that partially and fully discontinuous slabs have a higher ultimate shear strength and a better ductility than continuous slabs. Such findings are favourable as discontinuous systems also provide for easier construction, deconstruction and repair.

\section{Blind bolts}

The request for making a process of bolt mounting easier and faster led to the idea of using blind blots as demountable shear connectors. Blind bolts are specially designed connectors that could be installed from one side of a workpiece. Several comparative experimental and numerical analyses were performed [18-21, 25, 26, 48] as related to two types of blind bolts, both presented in Figure 8 . A blind bolt marked as BB2 should be put in a specialised tool that enables bolt installation, together with washers and a nut. On the other side, bolts marked as BB1 do not have parts that need to be assembled. Instead, they have a collar that spreads open after the bolt is secured. 

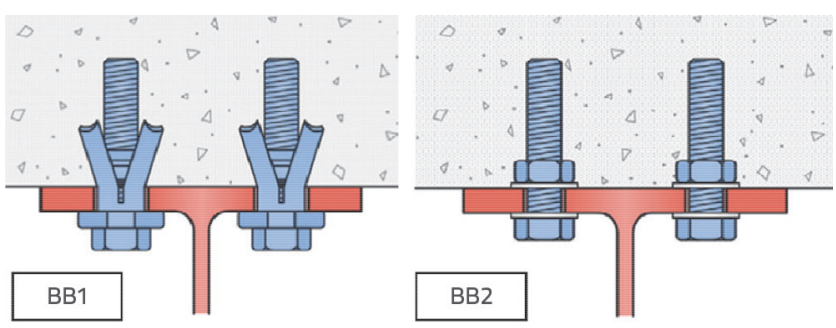

Figure 8. Blind boltsi [20]

Comparison of load-slip curves obtained for two types of blind bolts and welded studs [26] is presented in Figure 9. As results of push-out tests show, BB1 bolts have higher initial stiffness, but considerably smaller ductility and loadcarrying capacity before failure, when compared to BB2 bolts. While BB1 bolts failed due to concrete failure, bolt shear failure occurred in the push-out test of BB2 bolts. Authors suggest that an expended collar of the blind BB1 bolt provides additional inertia against slipping, but that the collar also causes damage of a concrete slab and brittle failure. On the other side, due to oversized holes in a steel flange, the specimen with BB2 bolts has a large initial slip. Low ductility of welded studs is attributed to poor welding and weld failure. Beam tests confirmed bolt properties relating to ductility and ultimate capacities obtained through push-out tests. Demountability is demonstrated on beam specimens with blind BB1 bolts, proving no considerable change in the load-deflection behaviour after reassembly.

\begin{tabular}{|l|c|c|c|c|}
\hline Ref. & Shear connector & $\begin{array}{c}\text { Diameter } \\
{[\mathrm{mm}]}\end{array}$ & $\begin{array}{c}\mathrm{f}_{\mathrm{/} / \mathrm{f}_{\mathrm{u}}} \\
{[\mathrm{MPa}]}\end{array}$ & $\begin{array}{c}\text { Concrete } \\
\text { cube strength } \\
\text { [MPa] }\end{array}$ \\
\hline$[26]$ & blind bolts BB1 & 20 & $860 / 920$ & $52.5^{*}$ \\
\hline$[26]$ & blind bolts BB2 & 20 & $795 / 900$ & $52.5^{*}$ \\
\hline$[26]$ & welded studs & 20 & $390 / 515$ & $52.5^{*}$ \\
\hline $\begin{array}{l}\text { *concrete cylinder strength is converted to concrete cube strength by } \\
\text { multiplying with 1.25 }\end{array}$
\end{tabular}

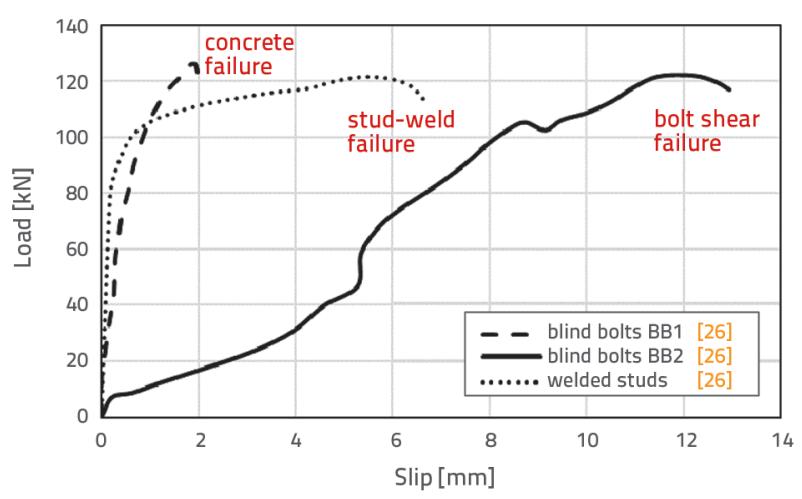

Figure 9. Comparison of shear connector behaviour

Besides behaviour of blind bolts in solid slabs under static loading tested in push-out and beam tests, the investigation on blind bolts also covered dynamic behaviour $[18,19]$, timedependent behaviour [20] and behaviour under combined shear and tension [48]. Implementation of blind bolts was suggested in both demountable composite beams $[25,26]$ and in bridge rehabilitation work $[21,26]$, the only difference being in the mounting process: in the latter case, holes were cored in a concrete slab and drilled in a steel flange from the top side of the specimen, then bolts were fixed and holes in the concrete slab were filled with grout. Nevertheless, a different mounting process did not significantly affect bolt behaviour.

\section{Bolted shear connectors with coupler system}

The attempts to make the process of bolt replacement simple led to the application of bolted shear connectors with a coupler system in composite steel-concrete floors. This connector consists of a bolt that is embedded in a concrete slab, a removable bolt that is placed from below, and a coupler system that connects two bolts, all as shown in Figure 10.

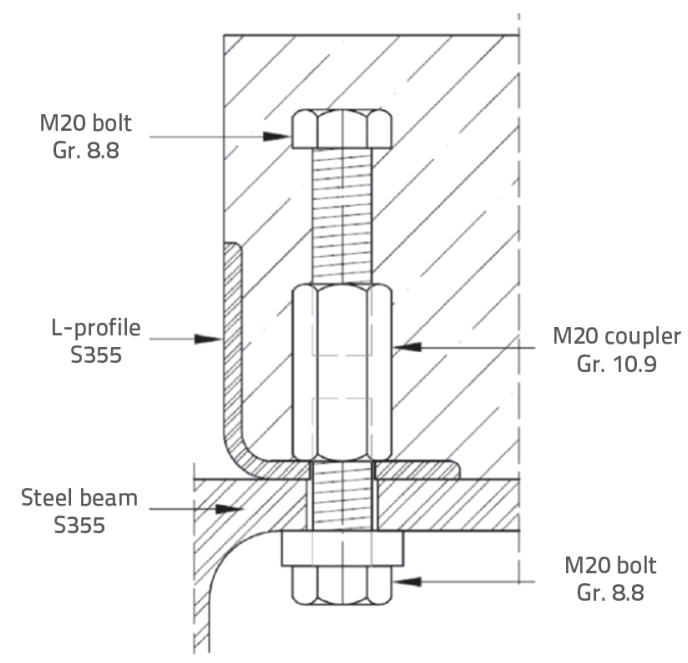

Figure 10. Bolted shear connector with a coupler system [36]

First analyses of this type of shear connectors were performed by varying the geometry of bolts and by comparing their response in push-out tests with welded headed studs [33]. The observed bolt failure mode was shear through threads of the removable bolt, while no concrete damage was noticed. As the authors concluded, the stiffness of the connection was highly influenced by the clearance between the bolt and hole in the steel flange.

In subsequent studies, another research group conducted comparative investigations of bolted shear connectors with a coupler system and friction-grip bolts cast in steel cylinders $[36,37]$. The benefit of bolt-coupler shear connectors over the friction-grip bolts was addressed considering the less likely bolt damage during construction and transport. As, similarly to single-nut and double-nut bolts, beams with 
installed coupler system exhibit additional deflections in the execution stage due to bolt slip, authors gave suggestions for solving this issue. Two types of the coupler system were investigated: pretensioned bolts and bolts with epoxy resin injected in the hole of the steel flange. Injected epoxy resin prevents decrease in stiffness and load-bearing capacity even when holes in steel flange are larger, which is beneficial from the aspect of prefabrication, execution, and deconstruction. For both types, a coupler was welded to the $L$ profile and a higher grade compared to that of the bolt was selected, because of the desired shear failure through threads of a lower bolt, which can easily be replaced. Pushout tests were conducted in solid slabs and they involved testing of both types of coupler connections, while the beam test included bolts with epoxy resin inserted in composite slab with profiled metal decking.

\begin{tabular}{|c|c|c|c|}
\hline Ref. & \multicolumn{2}{|c|}{ Shear connector } & $\begin{array}{c}\text { Concrete } \\
\text { cube strength } \\
\text { [MPa] }\end{array}$ \\
\hline$[36]$ & pretension coupler system & M20 8.8 & 44.3 \\
\hline$[36]$ & $\begin{array}{c}\text { coupler system with injected } \\
\text { resin }\end{array}$ & M20 8.8 & 44.3 \\
\hline$[36]$ & $\begin{array}{r}\text { friction-grip bolts cast in } \\
\text { steel cylinders }\end{array}$ & M20 8.8 & 59.4 \\
\hline$[26]$ & welded studs & $20 \mathrm{~mm}$ & 52.5 \\
\hline
\end{tabular}

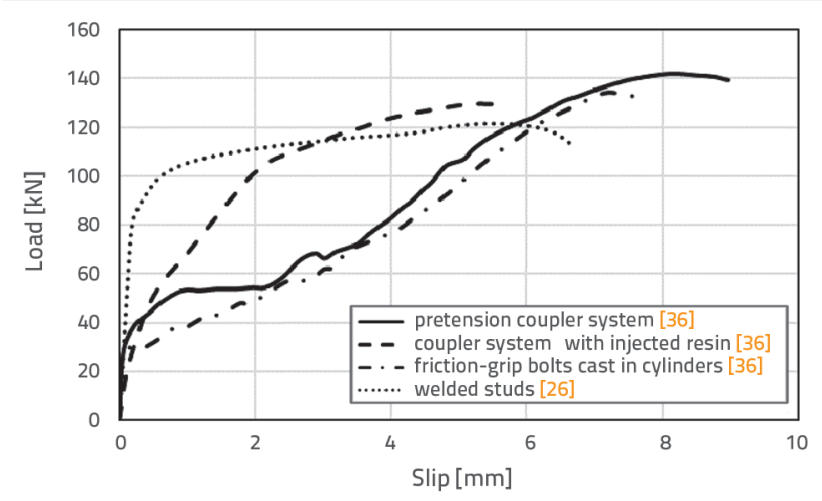

Figure 11. Comparison of shear connector behaviour

Recorded force-slip curves for the pretension bolt-coupler system, and the bolt-coupler system with epoxy resin, are compared in Figure 11 with the behaviour of friction-grip bolts cast in steel cylinders, tested by the same authors [36] and previously mentioned in Section 2, and with welded studs of the same diameter [26]. All presented connectors have comparable initial stiffness, although a drop in stiffness is observed after friction resistance is overcome for both types of bolts with applied pretension force. A coupler system with injected resin retained higher stiffness, but it was still lower compared to welded studs. Brittle shear failure of bolts occurred in all presented bolted connectors, and no other damage patterns were noticed. The epoxy resin remained unaffected. The bolt-coupler system with resin exhibited lower ductility than pretensioned bolts. Additional tests using bolt-coupler shear connectors with epoxy resin were performed on tapered composite beams, i.e. on the 90 $\%$ scaled replication of a typical beam used for multi-storey car park buildings [40]. By implementing different shear connector arrangements, it was intended to investigate if the reduction in connectors' number and their concentration near supports could provide sufficient resistance at the serviceability load range. Conclusions regarding approximately 40-50\% reduction of the number of shear connectors were made, suggesting an appropriate arrangement around the supports.

\section{Locking nut shear connectors and friction- based shear connectors}

Although characterised by different shear force transfer mechanisms, two types of demountable shear connector systems, developed by the same authors and characterized by certain similarities in geometry, i.e. the locking nut shear connector (LNSC) [29] and the friction-based shear connector (FBSC) [34], are presented here in the same section. The two systems were developed to overcome drawbacks of previously mentioned demountable shear connectors, such as the initial slip due to the bolt-hole clearance typical for threaded studs and bolts that are not preloaded, or a sudden slip after friction resistance is overcome in the case of preloaded bolts. LNSC and FBSC connectors were primarily developed for application in precast composite bridges, where they should be installed within pockets in the concrete slab, enabling fast assembly and disassembly. However, even though not purposely formed to be used in floors, the connectors are included in this review due to their original attribute - demountability.

Both systems consist of high strength bolts that are fastened by one nut to the upper steel flange and by another nut to the top surface of a concrete slab, as shown in Figure 12. The LNSC has an additional conical nut that is placed in the countersunk seat of a steel flange, and its purpose is to prevent bolt slip within the hole. Also, shear failure on the threaded part of the bolt is prevented by placing a conical nut in the shear plane between the steel flange and concrete slab. In the case of the FBSC, a retaining washer is used for placing the bolt in the right position. Countersunk holes are grouted to prevent a sudden slip of bolts. In both systems, bolts are placed in conical precast concrete plugs that are smaller than slab pockets, so as to avoid construction tolerance problems.

The typical failure mode of LNSCs and FBSCs, as observed during experimental push-out testing, was shear fracture 
a)

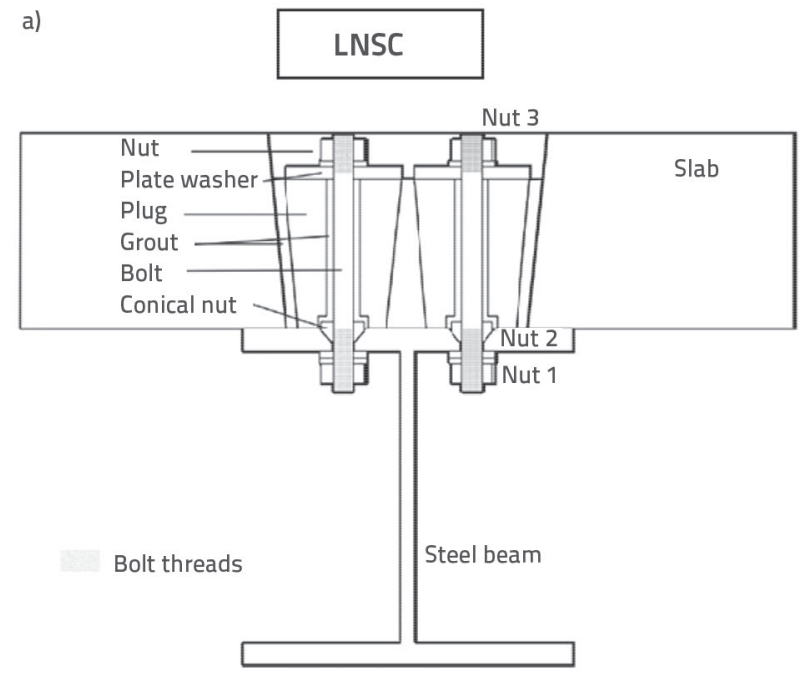

b)

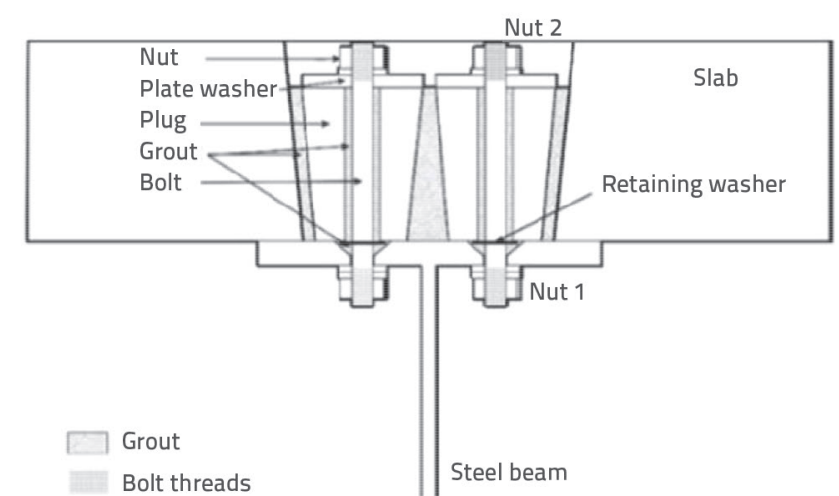

Figure 12. a) Locking nut shear connectors [29], b) riction-based shear connectors [34]

of a bolt just above the conical nut. Push-out tests showed very high initial stiffness of both systems, as well as a high slip capacity and ultimate strength. To get an insight into benefits of the suggested systems, force-slip curves for LNSC and FBSC are presented in Figure 13 against the curves for bolts with embedded nuts and friction-grip bolts cast in PVC cylinders, which are of similar diameter.

\begin{tabular}{|c|c|c|c|c|}
\hline Ref. & Shear connector & $\begin{array}{c}\text { Diameter } \\
{[\mathrm{mm}]}\end{array}$ & $\begin{array}{c}\mathbf{f}_{\mathbf{y}} / \mathbf{f}_{\mathrm{u}} \\
{[\mathrm{MPa}]}\end{array}$ & $\begin{array}{c}\text { Concrete } \\
\text { cube } \\
\text { strength } \\
{[\mathrm{MPa}]}\end{array}$ \\
\hline$[29]$ & LNSC & 16 & $787 / 889$ & 42.0 \\
\hline$[34]$ & FBSC & 16 & $787 / 889$ & 42.0 \\
\hline$[13]$ & $\begin{array}{c}\text { bolts with } \\
\text { embedded nuts }\end{array}$ & 16 & $640 / 800$ & 40.0 \\
\hline$[14]$ & $\begin{array}{c}\text { friction-grip } \\
\text { bolts cast in PVC } \\
\text { cylinders }\end{array}$ & 15.88 & $\begin{array}{c}\text { not specified } \\
\text { (ASTM A325) }\end{array}$ & $62.1^{*}$ \\
\hline
\end{tabular}

*concrete cylinder strength is converted to concrete cube strength by multiplying with 1.25

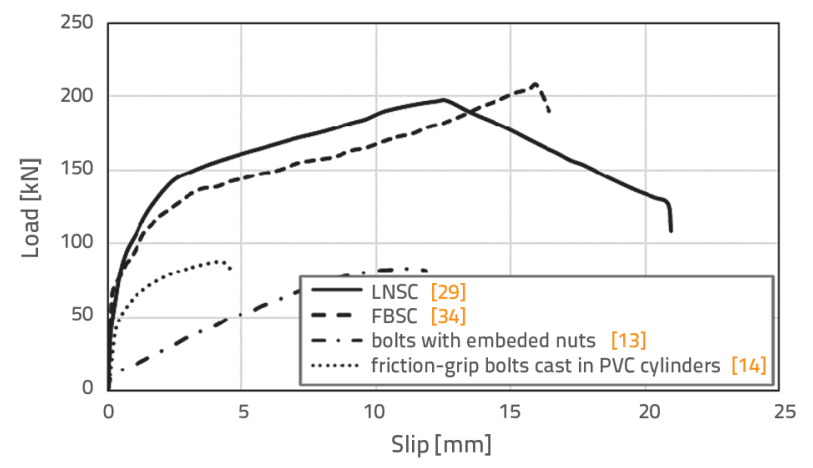

Figure 13. Comparison of shear connector behaviour
The complexity of two novel demountable systems from the aspect of geometry and requested material brings benefits such as an increase in stiffness, but also an approximately double increase in ultimate strength. Hence, the application of LNSCs and FBSCs in bridge girders requires fewer slab pockets than traditional welded headed studs or bolted connectors. Comparison of the two systems shows that the LNSC exhibits an increased ductility in the post ultimate domain.

\section{Steel-yielding demountable shear connectors}

A sophisticated solution regarding demountable shear connections in composite floors, specifically applicable in precast hollow-core slab units (HCU), has recently been proposed [41]. This solution greatly differs from all other previously described solutions, as it does not include bolted connectors as main shear-force transfer elements. It is included in this review as the only demountable solution proposed for implementation in hollow-core floors.

Traditionally, HCUs are used in combination with headed studs and rebars that are cast in concrete after mounting not allowing reassembly of the system. A solution proposed by authors, termed as a steel-yielding demountable shear connector (SYDSC), consists of a steel square hollow tube that is welded to the plate on its bottom side, forming the so-called yielding pocket, as shown in Figure 14.a. The plate is connected to the steel beam top flange via four high-strength bolts. For achieving ductile behaviour, the hollow tube has vertical holes that enable deformation of the yielding pocket under shear load, as presented in Figure 14.b. Around the connector, polythene foam is inserted to bring shear force above the base of a yielding pocket in the plane of vertical steel strips and holes, therefore avoiding brittle shear failure of bolts. Above the foam, a cast in-situ concrete layer is placed to enable shear 
a)

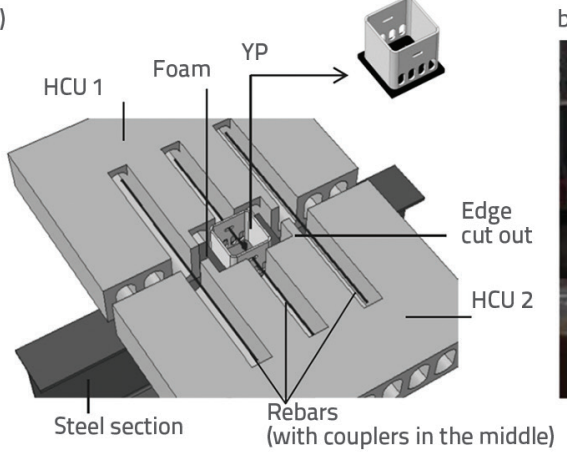

Figure 14. a) Steel-yielding demountable shear connector [41], b) Deformed shape of SYDSC [41]

force transfer between the yielding connector and concrete deck. Demountability is achieved as the connector is not fully embedded in concrete - the concrete layer around the yielding pocket can be easily cut and removed as well as the rebar passing through the connector, while bolts need to be unbolted. Importantly, the described layout solves construction tolerance problems.

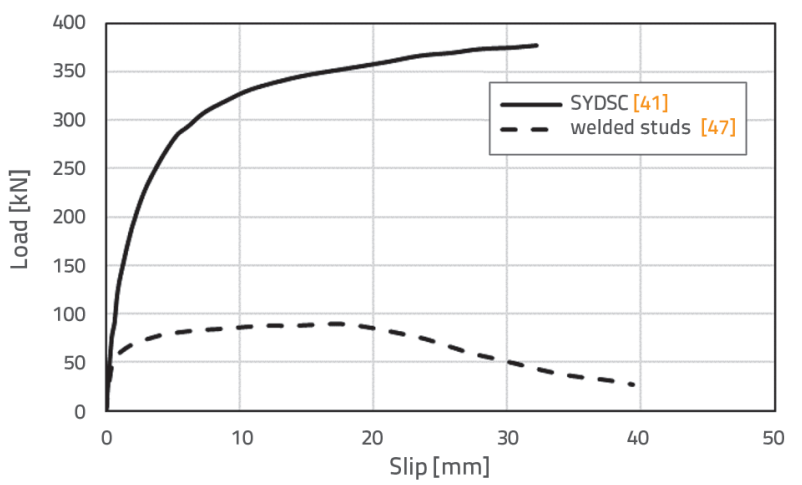

Figure 15. Comparison of shear connector behaviour

Push-out tests showed three failure modes, which were subsequently verified by numerical analysis: plastic deformation of the connector, concrete failure, and mixedmode failure, including both plastic deformation of the by adding shims. yielding pocket and concrete slab fracture. The representative force-slip curve obtained from the specimen that failed due to connector yield is given in Figure 15, where it is compared to some previously published results of the welded headed stud behaviour in HCUs [49]. As can be noticed, yielding pockets show high strength, initial stiffness and slip capacity, up to 30 $\mathrm{mm}$. Nevertheless, the cost of the improved response, reflected in terms of material consumption, should be kept in mind.

Additionally, authors suggest design equations for the steelyielding demountable connector, adding that the strength of the yield pocket should be smaller than concrete resistance in order to achieve a ductile response.

\section{Clamping shear connectors}

A system with clamping connectors was developed for transferring longitudinal shear force in demountable composite steel-concrete beams [42]. According to Figure 16, connectors made of clamps and high-strength T-bolts are mounted in cast-in channels in a prefabricated concrete slab. T-bolts are pretensioned, so that shear force is transferred through friction at the contact between the concrete slab and steel girder. The advantage of the developed system is adaptability, without predefined locations of bolt hole; it can therefore be applied if flange widths are changed after deconstruction. Also, if flange thickness is being modified, clamping connectors can be reused

The conducted push-out tests showed high initial stiffness, but very ductile behaviour of the analysed connectors, as presented through force-slip curves in Figure 17. However, in contrast to friction-grip bolts and pretension double-nut bolts of the comparable diameter and tensile strength, clamping connector reached approximately two times lower strength at $10 \mathrm{~mm}$ slip. This is explained by the specific failure mode of clamping connections, which is caused by large rotations of bolts, and bolt head fracture. In order to solve this problem and limit bolt rotations, further modifications of bolts are suggested. Moreover, surface fractures due to friction were observed in concrete planks, particularly at specimens with three cast-in channels, which were characterized by deeper and wider cracks than those of two channels. The authors formulated suggestions regarding design recommendations, based on the developed numerical model [42]. 


\begin{tabular}{|c|c|c|c|c|}
\hline Ref. & Shear connector & $\begin{array}{c}\text { Diameter } \\
{[\mathrm{mm}]}\end{array}$ & $\begin{array}{c}\mathbf{f}_{\mathbf{y}} / \mathbf{f}_{\mathrm{u}} \\
{[\mathrm{MPa}]}\end{array}$ & $\begin{array}{c}\text { Concrete } \\
\text { cube strength } \\
{[\mathrm{MPa}]}\end{array}$ \\
\hline$[42]$ & clamping connector & 24 & $759 / 940$ & $36.2^{*}$ \\
\hline$[10]$ & friction-grip bolts & 22 & $-/ 1020$ & $30.6^{*}$ \\
\hline$[10]$ & double-not bolts & 22 & $-/ 1010$ & $26.1^{*}$ \\
\hline
\end{tabular}

${ }^{*}$ concrete cylinder strength is converted to concrete cube strength by multiplying with 1.25

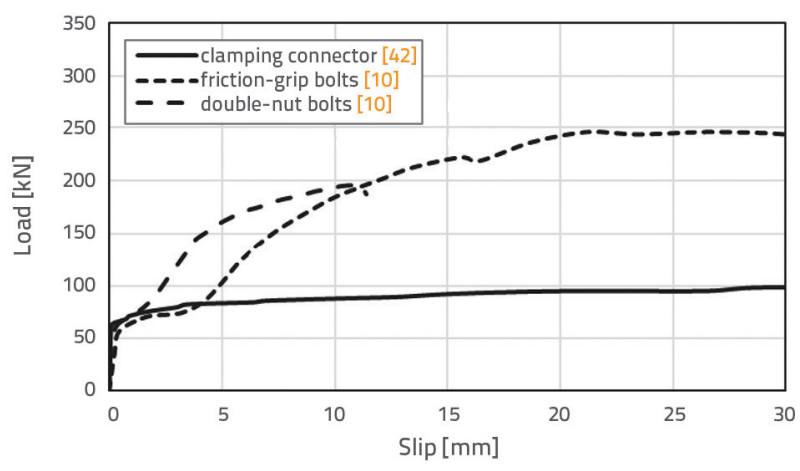

Figure 17. Comparison of shear connector behaviour

\section{Conclusions}

Many of the mentioned studies, for almost all types of demountable shear connectors, are still ongoing. The fact that a number of papers on LNSCs, FBSCs, steel-yielding connectors and clamping connectors have been published over the past two years suggests by itself that many novel patents and solutions could be expected in the future.

The evolution of demountable shear connector systems started with basic set-ups including very few components.
In order to compensate for certain weaknesses, more complex models have been established. However, the constant balance is to be made between a proper response of the structural system, fast and simple execution, and economical aspect.

Specific procedures in design codes for demountable steelconcrete composite structures are yet to be formulated and enacted. Firstly, it would be important to quantify shear strength of connectors through some general analytical expressions. Undoubtedly, in the case of bolted shear connectors, the implementation of the bolt shear resistance as given in Eurocode 3 [50] is inapplicable, due to the additional resistance achieved through the nut to flange friction and catenary effects in bolts [13].

Secondly, to enable structure reuse, it is necessary to limit, during the design process, the deformation of connectors and to avoid plastic response of beams. Some instructions concerning this issue have been given for the analysed connection with bolted shear connectors with embedded nuts, through study of an optimum span to depth ratio of demountable steel-concrete beams [51].

Other authors [36] emphasize that propositions given in Eurocode 4 [46] for experimental determination of connector ductility are inapplicable for certain demountable shear connectors. Namely, some bolted connectors feature different load-slip response than welded headed studs, as they exhibit large slip before reaching the ultimate strength, while welded studs reveal large deformations after reaching the ultimate load. Consequently, determination of slip capacity given in Annex B of Eurocode 4, corresponding to the $90 \%$ ultimate strength in the post-ultimate domain, cannot be implemented. As connector ductility directly influences design of beams with partial interaction, modifications of design rules should be considered.

\section{REFERENCES}

[1] Ahmed, I.M., Tsavdaridis, K.D.: The evolution of composite flooring systems: applications, testing, modelling and eurocode design approaches. Journal of Constructional Steel Research, 155 (2019) 1, pp. 286-300, https://doi.org/10.1016/j.jcsr.2019.01.007

[2] Gluhović, N.: Behaviour of shear connections realised by connectors fastened with cartridge fired pins. 2019.

[3] Brambilla, G., Lavagna, M., Vasdravellis, G., Castiglioni, C.A.: Environmental benefits arising from demountable steel-concrete composite floor systems in buildings. Resources, Conservation and Recycling, 141 (2019) 1, pp. 133-142, https://doi.org/10.1016/j. resconrec.2018.10.014

[4] Dallam, L.N.: Pushout tests with high strength bolt shear connectors. Missouri State Highway Department, 1968.

[5] Dallam, L.N., Harpster, J.L.: Composite beam tests with highstrength bolt shear connectors. Missouri State Highway Department, 1968.
[6] Marshall, W., Nelson, H., Banerjee, H.: An Experimental Study of the Use of High-Strength Friction Grip Bolts as Shear Connectors In Composite Beams. Structural Engineer, 49 (1971) 4, pp. 171178

[7] Dedic, DJ., Klaiber, F.W.: High-strength bolts as shear connectors in rehabilitation work. Concrete international, 6 (1984) 7, pp. 4146

[8] Hawkins, N.M.: Strength in Shear and Tension of Cast-in-Place Anchor Bolts. Special Publication, 103 (1987) 1, pp. 233-256, https://doi.org/10.14359/1677

[9] Sedlecek, G., Hoffmeister, B., Trumpf, H., Kühn, B.: EUR 20583 Steel structures: Composite bridge design for small and medium spans. Luxembourg, 2003.

[10] Kwon, G., Engelhardt, M.D., Klingner, R.E.: Behavior of postinstalled shear connectors under static and fatigue loading. Journal of Constructional Steel Research, 66 (2010) 4, pp. 532541, https://doi.org/10.1016/J.JCSR.2009.09.012 
[11] Kwon, G., Engelhardt, M.D., Klingner, R.E.: Experimental Behavior of Bridge Beams Retrofitted with Postinstalled Shear Connectors. Journal of Bridge Engineering, 16 (2011) 4, pp. 536-545, https:// doi.org/10.1061/(ASCE)BE.1943-5592.0000184

[12] Kwon, G., Engelhardt, M.D., Klingner, R.E.: Parametric Studies and Preliminary Design Recommendations on the Use of Postinstalled Shear Connectors for Strengthening Noncomposite Steel Bridges. Journal of Bridge Engineering, 17 (2012) 2, pp. 310-317, https:// doi.org/10.1061/(ASCE)BE.1943-5592.0000261

[13] Pavlović, M., Marković, Z., Veljković, M., Buđevac, D.: Bolted shear connectors vs. headed studs behaviour in push-out tests. Journal of Constructional Steel Research, 88 (2013) 1, pp. 134-149, https://doi.org/10.1016/j.jcsr.2013.05.003

[14] Chen, Y.T., Zhao, Y., West, J.S., Walbridge, S.: Behaviour of steel-precast composite girders with through-bolt shear connectors under static loading. Journal of Constructional Steel Research, 103 (2014) 1, pp. 168-178, https://doi.org/10.1016/J. JCSR.2014.09.001

[15] Moynihan, M.C., Allwood, J.M.: Viability and performance of demountable composite connectors. Journal of Constructional Steel Research, 99 (2014) 1, pp. 47-56, https://doi.org/10.1016/J. JCSR.2014.03.008

[16] Liu, X., Bradford, M.A., Lee, M.S.S.: Behavior of High-Strength Friction-Grip Bolted Shear Connectors in Sustainable Composite Beams. Journal of Structural Engineering, 141 (2015) 6, pp. 04014149, https://doi.org/10.1061/(ASCE)ST.1943$541 \times .0001090$

[17] Dai, X.H., Lam, D., Saveri, E.: Effect of Concrete Strength and Stud Collar Size to Shear Capacity of Demountable Shear Connectors. Journal of Structural Engineering, 141 (2015) 11, pp. 04015025 , https://doi.org/10.1061/(asce)st.1943-541x.0001267

[18] Henderson, I.E.J., Zhu, X.Q., Uy, B., Mirza, O.: Dynamic behaviour of steel-concrete composite beams with different types of shear connectors. Part I: Experimental study. Engineering Structures, 103 (2015) 1, pp. 298-307, https://doi.org/10.1016/j. engstruct.2015.08.035

[19] Henderson, I.E.J., Zhu, X.Q., Uy, B., Mirza, O.: Dynamic behaviour of steel-concrete composite beams with different types of shear connectors. Part II: Modelling and comparison. Engineering Structures, 103 (2015) 1, pp. 308-317, https://doi.org/10.1016/j. engstruct.2015.08.033

[20] Ban, H., Uy, B., Pathirana, S.W., Henderson, I., Mirza, O., Zhu, X.: Time-dependent behaviour of composite beams with blind bolts under sustained loads. Journal of Constructional Steel Research, 112 (2015) 1, pp. 196-207, https://doi.org/10.1016/j. jcsr.2015.05.004

[21] Pathirana, S.W., Uy, B., Mirza, O., Zhu, X.: Strengthening of existing composite steel-concrete beams utilising bolted shear connectors and welded studs. Journal of Constructional Steel Research, 114 (2015) 1, pp. 417-430, https://doi.org/10.1016/j. jcsr.2015.09.006

[22] Liu, X., Bradford, M.A., Chen, Q.J., Ban, H.: Finite element modelling of steel-concrete composite beams with high-strength frictiongrip bolt shear connectors. Finite Elements in Analysis and Design, 108 (2016) 1, pp. 54-65, https://doi.org/10.1016/J. FINEL.2015.09.004

[23] Ataei, A., Bradford, M.A., Liu, X.: Experimental study of composite beams having a precast geopolymer concrete slab and deconstructable bolted shear connectors. Engineering Structures, 114 (2016) 1, pp. 1-13, https://doi.org/10.1016/J. ENGSTRUCT.2015.10.041
[24] Rehman, N., Lam, D., Dai, X., Ashour, A.F.: Experimental study on demountable shear connectors in composite slabs with profiled decking. Journal of Constructional Steel Research, 122 (2016) 1, pp. 178-189, https://doi.org/10.1016/j.jcsr.2016.03.021

[25] Pathirana, S.W., Uy, B., Mirza, O., Zhu, X.: Flexural behaviour of composite steel-concrete beams utilising blind bolt shear connectors. Engineering Structures, 114 (2016) 1, pp. 181-194, https://doi.org/10.1016/j.engstruct.2016.01.057

[26] Pathirana, S.W., Uy, B., Mirza, O., Zhu, X.: Bolted and welded connectors for the rehabilitation of composite beams. Journal of Constructional Steel Research, 125 (2016) 1, pp. 61-73, https:// doi.org/10.1016/j.jcsr.2016.06.003

[27] Liu, X., Bradford, M.A., Ataei, A.: Flexural performance of innovative sustainable composite steel-concrete beams. Engineering Structures, 130 (2017) 1, pp. 282-296, https://doi.org/10.1016/J. ENGSTRUCT.2016.10.009

[28] Wang, J.Y., Guo, J.Y., Jia, LJ., Chen, S.M., Dong, Y.: Push-out tests of demountable headed stud shear connectors in steel-UHPC composite structures. Composite Structures, 170 (2017) 1, pp. 69-79, https://doi.org/10.1016/j.compstruct.2017.03.004

[29] Suwaed, A.S.H., Karavasilis, T.L.: Novel Demountable Shear Connector for Accelerated Disassembly, Repair, or Replacement of Precast Steel-Concrete Composite Bridges. Journal of Bridge Engineering, 22 (2017) 9, pp. 04017052, https://doi.org/10.1061/ (asce)be.1943-5592.0001080

[30] Rehman, N., Lam, D., Dai, X., Ashour, A.: Testing of composite beam with demountable shear connectors. Proceedings of the Institution of Civil Engineers - Structures and Buildings, 171 (2018) 1, pp. 3-16, https://doi.org/10.1680/jstbu.16.00172

[31] Yang, J., Lam, D., Dai, X., Sheehan, T.: Experimental study on demountable shear connectors in profiled composite slabs. Proceedings 12th international conference on Advances in Steel-Concrete Composite Structures - ASCCS 2018, Valencia: Universitat Politècnica València, pp. 115-121, 2018.

[32] Dai, X., Lam, D., Sheehan, T., Yang, J., Zhou, K.: Use of bolted shear connectors in composite construction. Proceedings 12th international conference on Advances in Steel-Concrete Composite Structures - ASCCS 2018, Valencia: Universitat Politècnica València, pp. 475-482, 2018.

[33] Yang, F., Liu, Y., Jiang, Z., Xin, H.: Shear performance of a novel demountable steel-concrete bolted connector under static pushout tests. Engineering Structures, 160 (2018) August 2017, pp. 133-146, https://doi.org/10.1016/j.engstruct.2018.01.005

[34] Suwaed, A.S.H., Karavasilis, T.L.: Removable shear connector for steel-concrete composite bridges. Steel and Composite Structures, 29 (2018) 1, pp. 107-123, https://doi.org/10.12989/ scs.2018.29.1.107

[35] Balkos, K.D., Sjaarda, M., West, J.S., Walbridge, S.: Static and Fatigue Tests of Steel-Precast Composite Beam Specimens with Through-Bolt Shear Connectors. Journal of Bridge Engineering, 24 (2019) 5, pp. 04019036, https://doi.org/10.1061/(ASCE)BE.19435592.0001382

[36] Kozma, A., Odenbreit, C., Braun, M.V., Veljkovic, M., Nijgh, M.P.: Push-out tests on demountable shear connectors of steelconcrete composite structures. Structures, 21 (2019) April, pp. 0-1, https://doi.org/10.1016/j.istruc.2019.05.011

[37] Odenbreit, C., Kozma, A.: Dismountable Flooring Systems for Multiple Use. IOP Conference Series: Earth and Environmental Science, vol 225IOP Publishing, pp. 012028, 2019. 
[38] Sencu, R.M., Wang, Y.C., Yang, J., Lam, D.: Performance evaluation of demountable shear connectors with collar step at ambient and elevated temperatures. Engineering Structures, 194 (2019) May, pp. 94-105, https://doi.org/10.1016/j.engstruct.2019.05.059

[39] Ataei, A., Zeynalian, M., Yazdi, Y.: Cyclic behaviour of bolted shear connectors in steel-concrete composite beams. Engineering Structures, 198 (2019) November 2018, pp. 109455, https://doi. org/10.1016/j.engstruct.2019.109455

[40] Nijgh, M.P., Gîrbacea, I.A., Veljkovic, M.: Elastic behaviour of a tapered steel-concrete composite beam optimized for reuse. Engineering Structures, 183 (2019) 1, pp. 366-374, https://doi. org/10.1016/J.ENGSTRUCT.2019.01.022

[41] Feidaki, E., Vasdravellis, G., He, J., Wang, S.: Steel-Yielding Demountable Shear Connector for Composite Floors with Precast Hollow-Core Slab Units. Journal of Structural Engineering, 145 (2019) 8, pp. 04019076, https://doi.org/10.1061/(ASCE)ST.1943$541 \times .0002356$

[42] Wang, L., Webster, M.D., Hajjar, J.F.: Pushout tests on deconstructable steel-concrete shear connections in sustainable composite beams. Journal of Constructional Steel Research, 153 (2019) 1, pp.618-637, https://doi.org/10.1016/j.jcsr.2018.10.020

[43] BS5400-5.: Steel, concrete and composite bridges Part 5: Code of practice for the design of composite bridges. London: BSI, 1979.

[44] Rowe, M., Bradford, M.A.: Partial Shear Interaction in Deconstructable Steel-Concrete Composite Beams with Bolted Shear Connectors. Design, Fabrication and Economy of Metal Structures - International Conference Proceedings, Miskolc, pp. 585-590, 2013.
[45] Fric, N.: Theoretical and experimental research of losses of pretension force in high strength bolts. 2015.

[46] EN1994-1-1.: Eurocode 4: Design of composite steel and concrete structures. Part 1-1: General rules and rules for buildings. Brussels: CEN, 2004.

[47] Todorović, M., Kovačević, S., Pavlović, M., Spremić, M., Marković, Z.: Behaviour of prefabricated steel-concrete composite bridge decks with grouped headed studs and bolted shear connectors. Proceedings of Eurosteel 2014, Naples, pp. 1-6, 2014.

[48] Tan, E.L., Varsani, H., Liao, F.: Experimental study on demountable steel-concrete connectors subjected to combined shear and tension. Engineering Structures, 183 (2019) 1, pp. 110-123, https://doi.org/10.1016/j.engstruct.2018.12.088

[49] Lam, D., Elliott, K.S., Nethercot, D.A.: Push-off Tests on Shear Studs with Hollow-cored Floor Slabs. The Structural Engineer, 76 (1998) 9, pp. 167-174

[50] EN1993-1-1.: Eurocode 3: Design of steel structures. Part 1-1: General rules and rules for buildings. Brussels: CEN, 2005.

[51] Girão Coelho, A.M., Lawson, R.M., Aggelopoulos, E.S.: Optimum use of composite structures for demountable construction. Structures, 20 (2019) 1, pp. 116-133, https://doi.org/10.1016/j. istruc.2019.03.005 